\title{
Spinoffs and tie formation in cluster knowledge networks
}

\author{
Sándor Juhász
}

Accepted: 19 July 2019 / Published online: 1 August 2019

(C) The Author(s) 2019

\begin{abstract}
It is generally acknowledged that in order to have access to locally accumulated industrial knowledge, firms have to collaborate and take part in cluster knowledge networks. This study argues that the inherited capabilities of spinoff enable them to cooperate and exchange knowledge more easily and to gain more from positive knowledge externalities in clusters. The basis of the analysis is a relational dataset on a printing and paper product cluster in Hungary, and I use exponential random graph models to explain the formation of knowledge ties. I demonstrate that besides geographical proximity, ownership similarity and network structural effects, being a spinoff company enhances tie formation in the local network. Results suggest that spinoffs are indeed more likely to collaborate and take advantage of knowledge concentration.
\end{abstract}

Keywords Spinoff - Knowledge network · Cluster Exponential random graph models

JEL classification codes D85 $\cdot \mathrm{L} 14 \cdot \mathrm{R} 11 \cdot \mathrm{O} 31 \cdot \mathrm{L} 26$

\footnotetext{
S. Juhász $(\bowtie)$

Agglomeration and Social Networks Lendület Research Group, Centre for Economic and Regional Studies, Hungarian Academy of Sciences, Tóth Kálmán u. 4, Budapest, Hungary

e-mail: juhasz.sandor@krtk.mta.hu

\section{S. Juhász}

Institute of Economics and Economic Development, Faculty of Economics and Business Administration, University of Szeged, Szeged, Hungary
}

\section{Introduction}

Industry clusters, the geographic concentrations of economic activities that operate in the same or interconnected sectors (Gordon and McCann 2000), foster higher innovation and economic performance of firms (Krugman 1991; Porter 1990; Cooke 2002). Their success is usually explained by agglomeration externalities (Rosenthal and Strange 2004; Tallman et al. 2004) that arise from labour market pooling, specialised suppliers and knowledge spillovers as Marshall (1920) described in his influential early works. Following this seminal contribution, scholars have emphasised the importance of localised knowledge spillovers on innovation and argued that it is mainly the geographical and social proximity of actors that help the circulation of new ideas from one firm to another, promoting the processes of incremental innovation and collective learning (Asheim 1996; Saxenian 1994; Audretsch and Feldman 1996; Maskell and Malmberg 1999).

The realisation that knowledge is not 'in the air' available for every actor in industrial concentration in contrast to the original idea of Marshall (1920) has increased the interest on social networks in clusters (Gordon and McCann 2000; Cooke 2002; Fornahl and Brenner 2003; Giuliani 2007). Giuliani and Bell (2005) show that knowledge is not diffused evenly in industry clusters, but circulates in local networks to which only a core group of firms characterised by advanced absorptive capabilities have access. This selective nature of local knowledge networks implies that firms are likely to differ in their ability to exploit and benefit from 
locally accumulated knowledge (Rigby and Brown 2015). Moreover, recent studies on cluster knowledge network formation demonstrated that along with individual capabilities and skills of firms, the establishment of local network ties is also influenced by the proximity of firms and the network structure itself (e.g. Broekel and Boschma 2012; Giuliani 2013; Balland et al. 2016).

Besides positive externalities and knowledge spillovers, clustering has also been explained through the formation of spinoff companies (Klepper 2007, 2010, 2011; Buenstorf and Klepper 2009; Boschma 2015; Qian 2018). Spinoffs, the new companies founded by employees of incumbent firms in the same industry, tend to locate close to their parents (Dahl and Sorenson 2012), which helps the reproduction of clusters over time. Moreover, their superior inherited capabilities help them perform better than other firms (Klepper 2009). In recent years, the special role and importance of spinoffs in clusters have been investigated by several empirical studies (e.g. Feldman et al. 2005; Klepper 2007, 2010; Heebels and Boschma 2011; Wenting 2008; Morrison and Boschma 2019), and most of these works have highlighted the importance of pre-entry background in order to benefit from clustering and locally accumulated knowledge (Buenstorf and Klepper 2009, 2010; Boschma 2015). However, there is still a lack of evidence as to whether the acquired capabilities, routines or relationships of spinoffs matter in order for firms to collaborate and form ties in cluster networks.

The main aim of this article is to emphasise the role of spinoff companies in clusters by showing their outstanding ability to form local knowledge ties. I argue that because of their pre-entry experience and inherited capabilities, spinoffs form knowledge ties more efficiently and therefore gain more from locally accumulated industrial knowledge. It is important to stress these questions as it is still unclear whether spinoffs are generally more capable to collaborate and embed in cluster networks than other firms. Furthermore, the general aim of this paper is to combine the emerging literature on cluster knowledge networks and the literature on spinoffs. In order to meet these expectations, I focus on the mature cluster of printing and paper product industry in Kecskemét, Hungary. The analysis rests on relational data on the informal technological knowledge exchange of firms, collected through face-to-face interviews in 2012. Besides testing for the influence of spinoff background in knowledge tie formation, I control for other node-level firm characteristics, dyad-level proximities of companies and network structural properties by applying exponential random graph models (ERGMs).

The empirical results show that spinoff companies are more likely to be connected to other firms in the cluster than non-spinoffs. I also found that there is more collaboration inside domestic and foreign ownership groups than there is between them and the geographical proximity of actors also enhances networking. Controlling for the structure of the network, I found that the formation of triads and mutual relationships had a significant influence on knowledge sharing. The findings support the arguments that spinoff companies are more likely to form knowledge ties in clusters and that their inherited capabilities enable them to get better access to local industrial knowledge. To further strengthen these arguments and explain the possible reasons behind the superior capabilities of spinoffs to form network ties, a detailed discussion is provided on the formation of the specific cluster.

The structure of the article is as follows. Section 2 reviews the literature on knowledge networks and spinoffs in clusters. In Section 3, I present the context of the analysis and the data collection process, while in Section 4 I detail the applied statistical method to analyse network formation. Section 5 presents the results of the applied ERGMs. The main conclusions, discussion over the implications and promising future research directions are presented in Section 6.

\section{Knowledge sharing, networks and spinoffs in clusters}

\subsection{Knowledge networks in clusters}

A crucial contribution to understanding the success of clusters was the realisation that geographical proximity in itself does not necessarily help firms in specialised industries, but it is rather the case that social networks play an important role in innovation and learning (Sorenson and Audia 2000; Owen-Smith and Powell 2004). As Giuliani (2007) shows in her studies, knowledge is 'not in the air' available for everyone in industry clusters, as in Marshall's original impressions, but it circulates only in selective local knowledge networks. Knowledge networks link firms through the transfer of innovation-related knowledge, by the joint solution of complex technical problems (Giuliani 2010). In order to 
benefit from the locally accumulated industrial knowledge, firms must take part in these networks, which requires skills and capabilities to transfer and exploit knowledge through collaboration. Therefore, knowledge in clusters flows mainly within a core group of firms characterised by strong knowledge bases and advanced absorptive capacity (Giuliani and Bell 2005).

Being strongly connected to firms in the local knowledge network tends to increase innovative performance, but so do connections to extra-regional knowledge sources (Boschma and Ter Wal 2007; Morrison et al. 2013). Firms who build linkages to actors outside the region with the purpose of learning and knowledge sharing can bring new, non-redundant knowledge to the cluster, increase international competitiveness and help to avoid the technological lock-in of the cluster (Bathelt et al. 2004). However, geographical proximity and face-to-face connections are still key to exchange, combine and re-combine tacit knowledge for innovation and learning (Audretsch and Feldman 1996; Gertler 2003). Empirical evidence supports these theories by illustrating that the geographical proximity of actors influences the establishment of collaboration in clusters, as physical closeness facilitates frequent face-to-face contacts and reduces the costs of creating relationships (Broekel and Hartog 2013a; Balland et al. 2016; Juhász and Lengyel 2018).

Besides the geographical closeness of actors, other forms of proximities can enhance collaboration and facilitate knowledge transfer in clusters (Knoben and Oerlemans 2006; Ter Wal and Boschma 2009; Boschma and Frenken 2010). Cognitive proximity, the similarity between the technological profiles of firms, makes knowledge transfer accessible as they understand each other better and can expect more accurate and useful advice for their technical problems. Empirical studies also showed that institutional proximity, the similarity in the legal forms of organisations, could help collaboration and knowledge exchange as related routines and incentive mechanisms might influence the willingness to cooperate (Broekel and Hartog 2013a; Balland et al. 2016).

Furthermore, the actors' decision to collaborate and form knowledge ties in clusters is influenced by the network structure of existing relationships (Ter Wal and Boschma 2009; Boschma and Frenken 2010). Social tie formation, in general, is often path dependent and depends on the structure of relationships itself, which applies to cluster networks as well (Glückler
2007). Triadic closure, the notion that partners of partners become partners, enhances the formation of collaboration ties in the cluster (Giuliani 2013; Broekel and Hartog 2013a; Balland et al. 2016). As actors become more embedded in the network through closed triads, cohesion and the level of trust increase, which further facilitates knowledge sharing and collaboration inside the clusters. Reciprocity, the mutuality of technical advice in cluster knowledge networks, also increases the level of trust, stabilises relationships and improves the quality of interaction (Giuliani 2013; Balland et al. 2016).

In summary, firms in clusters have to collaborate in local knowledge networks to take advantage of colocation and knowledge externalities. Most of the above literature is focused on how and why firms form linkages to exploit locally accumulated knowledge. The participation in these knowledge networks requires advanced capabilities and skills, but besides firm-level characteristics, the formation of network ties is influenced by both the similarity of firms and the network structure itself. In the next subsection, I describe the role of spinoff companies in cluster knowledge networks. Due to their inherited competences, spinoffs could possibly participate in cluster networks more easily; however, their role in knowledge networks is still not clear.

\subsection{Spinoffs in clusters}

Until recently, the explanation of industry clustering was dominated by the Marshallian view based on positive local externalities (Rosenthal and Strange 2004; Tallman et al. 2004). As the industry started to develop in a region, local externalities were believed to support growth, further firm entries and overall prosperity in the cluster (Boschma 2015). These arguments were challenged by Steven Klepper and his collaborators, who argued that organisational reproduction and inheritance through spinoff formation are behind the strength and success of clusters (Klepper 2007, 2010; Buenstorf and Klepper 2009, 2010).

As companies try to enhance their own performance through continuous technological development and organisational process improvements, successful incumbents inevitably function as training grounds for their employees, allowing them to learn the skills needed to start their own venture. Therefore, the competence of new entrants depends on their heritage, their pre-entry experiences and the accumulated industrial and 
organisational knowledge. In practice, these could originate from experience within existing markets and established routines, or from the tacit knowledge of employees which is transferred through the spinoff process (Agarwal et al. 2004; Nelson and Winter 1982). Spinoffs also tend to locate close to their geographic roots where their founders worked and collected knowledge and experiences before (Buenstorf and Klepper 2010). The reasons why spinoffs often stay near to their parents could be the need to gain access to specialised local suppliers and services (Boschma 2015) or the high relocation costs which include the 'opportunity cost' of losing local networks (Dahl and Sorenson 2012). As a result, spinoffs fuel the concentration of industries through an endogenous process governed by the supply of capable entrants.

Several empirical studies have shown that spinoffs tend to perform better and have a higher survival rate than other firms in clusters (e.g. Carias and Klepper 2010; Klepper 2010; Boschma and Wenting 2007; Buenstorf and Guenther 2011; Wenting 2008). The common explanation of why spinoffs stand out in clusters is that their superior inherited capabilities make them more able to benefit from Marshallian externalities (Klepper 2007, 2010; Buenstorf and Klepper 2010; Cusmano and Morrison 2015). However, there is still limited evidence on how spinoffs behave and form relationships in cluster knowledge networks to access the accumulated industrial knowledge. Ter Wal (2013) shows, on a comparative basis, that small local spinoffs perform a key role in the establishment of dense collaboration networks in clusters. Furthermore, Bagley (2018) demonstrates that the personal ties of founders to parent companies influence the performance of spinoffs in clusters.

As previous studies highlighted that only firms with advanced capabilities are able to collaborate and share knowledge in industry clusters, I suggest that spinoff companies are more likely to form relationships in cluster networks. I assume that their inherited routines and capabilities enable them to cooperate and establish ties of knowledge sharing more easily. Because of their preentry experience, they can be more familiar with the capabilities and knowledge of other local actors. This can help them search for technical knowledge and find a solution in a critical situation more efficiently. Their previously acquired skills can also enable them to interact, communicate and exchange technical knowledge in a more effective way. As a consequence, spinoffs could gain more from industrial concentration and positive externalities by exploiting more knowledge through collaboration. Even though the actual capabilities and routines that spinoffs inherited are hardly observable, their significance can be inferred from looking at the effect of spinoff background on tie formation, while controlling for node level, dyad level and structural properties at the same time.

\section{Context and data}

\subsection{A printing and paper product cluster in Hungary}

The focus of this study is on a printing and paper product cluster in Kecskemét, Hungary. Kecskemét is a middle-sized town with approximately 112,000 inhabitants about $80 \mathrm{~km}$ south of Budapest, the capital city of Hungary. Its economy is rooted in agriculture, processing and manufacturing industries. The printing industry has a long tradition in the region as the first printing house, the Petöfi Press, was established in the 1840s and is still working under this name. After the collapse of the planned economy in Hungary, it became possible to found privately owned enterprises. As a result, by the early 1990s, numerous small and medium printing presses were founded around the town of Kecskemét.

As the old Petófi Press functioned as a training ground for their employees, many spinoff companies emerged in the early 2000s. Combined with international companies that also located their facilities there (e.g. Ringier Axel Springer Media AG), nearly 40 companies are now operating in the sector throughout the town. In 2012, the location quotient based on the number of employees showed a significant relative concentration of both the printing and service activities related to printing $(\mathrm{LQ}=$ 1.059) and the manufacture of articles of paper and paperboard $(L Q=4.602)$. Detailed explanations of the location quotient and the concentration of manufacturing subsectors can be found in the Appendix (Tables 4 and 5). The intense local competition requires flexible specialisation of firms and the local industry as such. Most of the companies base their main activity on specialised technological solutions for creating unique paper products (such as specifically printed and folded paper products; stickers, labels and other packaging materials). Firms typically do not carry out R\&D activities; they mainly build on customer-driven process-oriented innovations and mature technological knowledge. 
As I discovered during my interviews, there is a strong informal network behind the cluster, which is characterised by the personal interactions of technicians that search for advice on technical issues. For example, they may ask for advice on specific paper types or experience with new printing machines. Altogether, the local industry can be characterised as an old social network-based cluster (Iammarino and McCann 2006), and it provides suitable conditions for analysing the social networks behind it.

\subsection{Data collection}

The sample selection is based on The Company Code Register (2011) by the Hungarian Central Statistical Office. This is a firm-level, nationwide database with basic information and statistics on companies, including seat addresses and classification of main activities. All the firms with a minimum of two employees, who have a company location within the urban agglomeration of Kecskemét and whose main activities are classified under the industry code 17 (manufacture of paper and paper products) or 18 (printing and reproduction of printed media) in the Statistical Classification of Economic Activities of Eurostat (2008), were selected. Of these, 38 firms met the above criteria and some companies with identical addresses and similar names had also merged. This resulted in a sample of 35 firms with which to begin the data collection.

The necessary relational data was collected at the firm level on the basis of face-to-face interviews. All the interviews were conducted with skilled workers (mostly with co-founders, operational managers or foremen), who were able to accurately answer the questions. The interviews were structured by a questionnaire in order to get detailed information on firms and their relationships. The data on cooperation ties was collected by the roster recall method (Wasserman and Faust 1994) where each firm was presented with a complete list (roster) of the other firms and was asked to report about their relations to all the other firms. The following question was used to collect relational data on knowledge sharing in the cluster:

If you are in a critical situation and need technical advice, to which of the local firms mentioned in the roster do you turn?
This question is formed to collect relational data on knowledge exchange and has been used previously by numerous studies on cluster knowledge networks (e.g. Giuliani and Bell 2005; Morrison and Rabellotti 2009). The question targets the transfer of technical and innovation-related knowledge, and it only reveals collaboration-based problem solving and technical assistance inside the cluster (Giuliani and Bell 2005). It is meant to capture the transfer of complex contextualised knowledge and not simply the transfer of basic information. The roster was left open in the sense that respondents could also add further contacts that did not already appear on the list. As many firms indicated knowledge exchange in relation to a company that mainly engineers knives and heavy machinery for paper product creation, I also interviewed this frequently mentioned company.

Besides capturing interfirm knowledge ties, additional questions were formed to collect data on firm size, interregional knowledge ties, ownership and spinoff background of firms. It is possible to characterise three types of entrants into an industry in terms of their preentry experience and inherited competences: start-ups, diversifiers and spinoffs (Buenstorf and Klepper 2010). In this study, I focus only on spinoff companies and distinguish firms only as spinoffs or non-spinoffs.

\subsection{Descriptive statistics of the sample}

I acquired 26 responses from companies, which resulted in an above $70 \%$ coverage of the original selection. As the list of firms was compiled on the basis of a dataset from 2011, it turned out that eight of the companies had closed down or had temporarily suspended their business activities. Only one actor refused to answer the questions and all of the non-respondents were domestic small- and medium-sized enterprises (SMEs). I also compared the average years in the industry and the average size of firms between non-respondents and the final sample and obtained very similar values for both groups. As a result, a 'non-respondent bias' was not detected (Armstrong and Overton 1977; Lambert and Harrington 1990). Moreover, I encouraged firms to mention knowledge exchange with any other companies in the region not presented in the roster. As a result, I also interviewed the one frequently mentioned firm. I believe that I captured all the companies in the printing and paper product industry around Kecskemét and the data collection was inclusive. 
As Table 1 shows, the majority of the companies in the final sample are domestic SMEs. There is only one firm with more than 100 employees and only a minority of them are foreign-owned (less than 25\%). The average number of extra-regional knowledge ties is 7.4, and apart from three companies, all firms exchange knowledge with other firms outside the region. The average amount of time firms had spent in the industry was above 14 years, and more than $75 \%$ of the companies had above 10 years of experience in the printing and paper product industry. In addition to this, 11 out of 26 of the actors interviewed said that their company was a spinoff and the majority of them verified themselves as spinoffs of Petöfi Press, which is the oldest and still the most prominent printing press in the region. Table 1 also shows that the group of spinoffs and non-spinoffs have relatively similar characteristics at the firm level.

Based on the question about knowledge transfer between firms, I construct a directed adjacency matrix with $n$ rows and $n$ columns (where $n$ stands for the number of respondents). In this matrix, each cell indicates the transfer of knowledge from the firm $i$ in the row to firm $j$ in the column. The cell $(i, j)$ contains the value of 1 if the company $i$ have given advice to company $j$, and contains the value of 0 in cases where no knowledge

Table 1 Firms' characteristics

\begin{tabular}{|c|c|c|c|}
\hline & $\begin{array}{l}\text { Spinoffs } \\
(n=11)\end{array}$ & $\begin{array}{l}\text { Non-spinoffs } \\
(n=15)\end{array}$ & $\begin{array}{l}\text { Full sample } \\
(n=26)\end{array}$ \\
\hline \multicolumn{4}{|c|}{ Ownership } \\
\hline Foreign & 2 & 4 & 6 \\
\hline \multicolumn{4}{|c|}{$\begin{array}{l}\text { Do- } \\
\text { mestic }\end{array}$} \\
\hline \multicolumn{4}{|c|}{ Extra-regional knowledge ties } \\
\hline 0 & 2 & 1 & 3 \\
\hline $1-10$ & 8 & 10 & 18 \\
\hline $11-50$ & 1 & 4 & 5 \\
\hline \multicolumn{4}{|c|}{ Years in the industry (age) } \\
\hline $1-10$ & 3 & 5 & 8 \\
\hline $11-20$ & 6 & 7 & 13 \\
\hline $21-25$ & 2 & 3 & 5 \\
\hline \multicolumn{4}{|c|}{ Employees } \\
\hline $2-5$ & 5 & 7 & 12 \\
\hline $6-50$ & 4 & 6 & 10 \\
\hline $51-400$ & 2 & 2 & 4 \\
\hline
\end{tabular}

Source: Author's own data
Table 2 Descriptive statistics of the knowledge network

\begin{tabular}{lc}
\hline Attribute & Value \\
\hline Nodes & 26 \\
Edges & 223 \\
Density & 0.343 \\
Average degree & 17.154 \\
Average distance & 1.72 \\
\hline
\end{tabular}

Source: Author's own data

has been transferred. Based on this adjacency matrix, I created a directed, unweighted graph which represents the knowledge network behind the cluster.

The knowledge network of the printing and paper product cluster in Kecskemét consists of 26 nodes and 223 edges (Table 2). In this relatively dense network, actors exchange knowledge with around 17 other firms and the distances between companies are very short. The visual representation also suggests (Fig. 1) that the cluster is based on an intensive, informal collaboration network where some of the most influential actors are spinoffs.

\section{Methodology and variables}

\subsection{Exponential random graph models}

In order to better understand the role of spinoffs in the formation of cluster knowledge networks, ERGMs are applied (Snijders et al. 2006; Lusher et al. 2013). ERGMs are stochastic models that approach tie formation as a time-continuous process. They are built on an observed network at one point in time, which is a particular realisation out of a set of hypothetical networks with similar properties. The aim of ERGMs is to identify the factors that maximise the probability of the emergence of a network with the same properties as the structure of the observed network (Broekel et al. 2014). The general form of exponential random graph models is as follows (after Robins et al. 2007a):

$\operatorname{Pr}(X=x)=\left(\frac{1}{k}\right) \exp \left\{\sum_{A} \eta_{A} g_{A}(x)\right\}$

where the summation is overall configurations $A . \eta_{A}$ is the parameter corresponding to configuration $A$ (and is non-zero only if all pairs of variables in $A$ are assumed to be conditionally dependent on the rest of the graph). These configurations can contain factors related to the 
Fig. 1 The local knowledge network of the printing and paper product industry in Kecskemét in 2012. (Author's own data.) The size of the nodes is proportional to in-degree

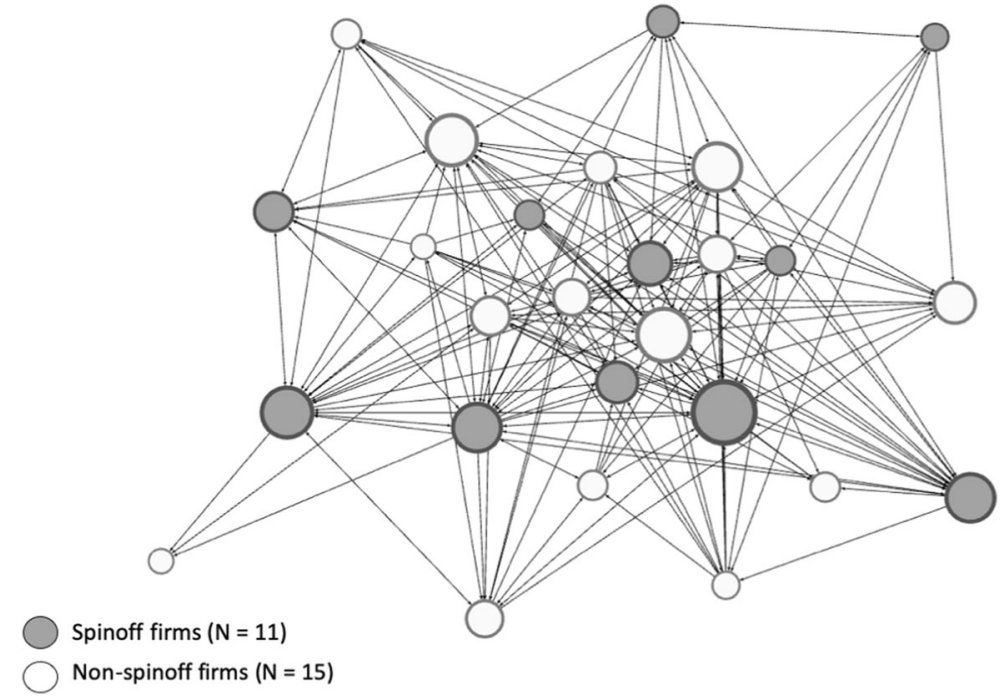

node level, dyad level and structural level. $g_{A}(x)=\prod_{x_{i j} \in A} x_{i j}$ is the network statistic corresponding to configuration $A \cdot g_{A}(x)=1$ if the configuration is observed in the network $x$, and is 0 otherwise. $k$ is a normalising constant ensuring that the equation is a proper probability distribution (summing up to 1 ). It is defined as:

$k=\sum_{X} \exp \left\{\sum_{A} \eta_{A} g_{A}(x)\right\}$

where $X(n)$ represents all the possible networks with $n$ nodes. Consequently, the probability of observing any particular graph $x$ in this distribution is given by the equation, and this probability $\operatorname{Pr}(X=x)$ depends on the network statistics $g_{A}(x)$ in the network $x$ and on the parameters represented by $\eta_{A}$ for all considered configurations $A$. The value of $\eta_{A}$ indicates the impact of the configuration on the log-odds of the appearance of a tie between two nodes.

In an ERGM estimation, the equation is solved such that parameter values are identified for each configuration that maximises the probability that the simulated network is identical to the empirically observed one. This is achieved by Markov chain Monte Carlo maximum likelihood estimation (for more details, see Snijders 2002; van Duin et al. 2009). The procedure is based on the generation of random graphs by stochastic simulation from a starting set of parameter values. These parameter values are subsequently refined through the comparison of the obtained random graphs against the observed graph. The process is repeated until the parameter estimates stabilise. In cases where they do not, the model might prove to be unstable and fail to demonstrate convergence (for more technical details, see Hunter et al. 2008). The above-described procedure is implemented in the statnet $\mathrm{R}$ package (see Robins et al. 2007b; Goodreau et al. 2008).

In order to check whether the given parameters predict the observed network well, the 'goodness of fit' test is carried out in order to compare the structure of the simulated networks with the structure of the observed network. Suggested by Hunter et al. (2008), the comparison is usually made on the basis of degree distribution, distribution of edgewise shared partners (the number of links in which two actors have exactly $k$ partners in common, for each value of $k$ ) and the minimum geodesic distance (the number of pairs for which the shortest path between them is of length $k$, for each value of $k$ ). The more these statistics are similar for the estimated and observed networks, the more accurate and reliable estimated parameters of the ERGMs are. Additionally, along with the iterations, the simulated parameter values should be relatively stable and vary more or less around the mean value (Goodreau et al. 2008). All the suggested goodness-of-fit statistics in relation to the final model are presented in the Appendix (Figs. 4 and 5). In case of a successful estimation, the given parameters of the ERGM can be interpreted as nonstandardised coefficients obtained from logistic regression analysis, which can be transformed into odds ratios.

Through ERGMs, I can examine how node-level, dyad-level and network-level characteristics influence 
tie formation in a network, observed only at a certain point in time. Because of these relatively low-level barriers, the application of ERGMs became popular in social sciences. However, only a handful of studies use ERGMs on networks of innovation and knowledge (Broekel and Hartog 2013b; Capone and Lazzeretti 2016; De Stefano and Zaccarin 2013) and only a minority of them focuses on cluster knowledge networks (Broekel and Hartog 2013a; Molina-Morales et al. 2015; Capone and Lazzeretti 2018).

\subsection{Variables}

It is possible to include variables to ERGMs in three different levels. Node-level variables capture how individual properties influence tie formation. Dyad-level variables capture how similarity of actors influences the probability that actors form ties. Structural-level variables try to capture the influence of network structure on tie formation. In order to observe how spinoffs influence learning and knowledge sharing in clusters, I do not only use node-level variables but also controls for several dyadic and structural effects as well.

The most important node-level factor in this study is whether a company is established as a spinoff or not. Through a node-level spinoff dummy, I examine how spinoff background influences tie formation in the cluster knowledge network. I expect that spinoffs form significantly more ties in the cluster than they would in a random setting. Additionally, firm-level control variables such as ownership, age, external knowledge ties and number of employees are included. By adding a foreign company dummy, I control for group homophily, or in other words, whether firms tend to share knowledge in their own ownership group. Firms are foreign-owned in my sample if they are at least partly owned by foreign companies. Age refers to the years of experience in the printing industry. External knowledge ties as possible sources of new knowledge and novel technological solutions are key in the cluster literature (Bathelt et al. 2004; Glückler 2007; Morrison 2008). To measure the importance of extra-regional relationships as a node-level characteristic, the number of external knowledge ties (meaning all the links to other regions in Hungary or abroad) is included. The number of employees in a logarithmic form is used to provide a control for the size of the firms, as it could determine firms' ability to acquire knowledge in clusters (Parra-Requena et al. 2010).
Two control variables are also included at the dyad level. The geographical proximity of firms is measured as the distance of the selected pair of firms subtracted from the maximum physical distance between firms in the cluster. As a result, the variable takes a higher value as the distance between firms diminishes (Juhász and Lengyel 2018). Cognitive proximity is made operational as the number of digits the two firms have in common in their 4-digit NACE codes (Balland et al. 2016). This measure assumes that the technological profiles of firms have greater similarity and, therefore, that they are cognitively closer if they operate in the same sector category (Frenken et al. 2007). The descriptive statistics of the applied geographical and cognitive proximity measures are provided in the Appendix (Tables 6 and 7).

To control for the structural dependencies, three variables at the network level are included. Triadic closure is captured by the geometrically weighted edgewise shared partner statistics (GWESP). They measure the number of triangles in the network while taking into account the number of ties that are involved in multiple triangles and hence connect the same neighbours in multiple triads (Hunter et al. 2008). In cases when the parameter is positive and significant, there is a tendency towards triadic closure in the network. Geometrically weighted dyad-wise shared partners (GWDSP) are also included. They measure the extent to which nodes are not directly linked to each other, being at least indirectly linked (Snijders et al. 2006). In other words, they capture the multi-connectivity of nodes that are not directly linked through the approximation of indirect existing paths between such nodes. Geometrically weighted in-degree statistics (GWIDEGREE) are also included to model the observed network's in-degree distribution. They allow us to model the preferential attachment processes. Moreover, two baseline structural control variables are also included. EDGES equal the number of links in the network and are used as overall network structural controls. They compare the density of the observed network with the density of the simulated exponential random graphs. MUTUAL ties provide controls for reciprocity in tie formation. Both of these effects are necessary to control for in every (directed) ERGM.

\section{Results}

Figure 2 presents some general descriptive statistics on the position of spinoff companies in the knowledge 

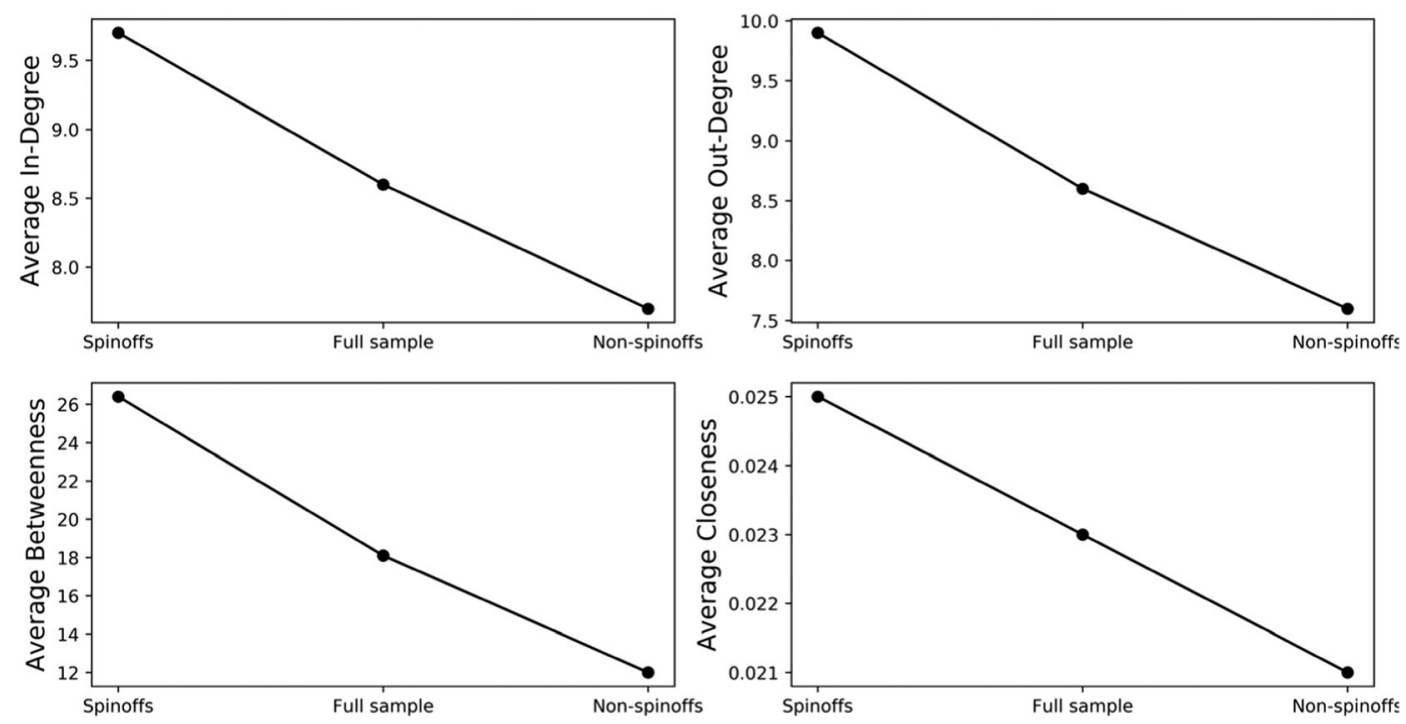

Fig. 2 Descriptive statistics on the network position of spinoff companies. (Author's own data.) Dots represent group average of in-degree, out-degree, betweenness centrality and closeness centrality for spinoff companies, for the full sample and for non-spinoff companies

network. It shows that spinoffs on average have more incoming and outgoing ties than other actors. This suggests that spinoffs tend to form more ties to exchange technical knowledge within the cluster. Spinoff companies also have higher than the average value of 'betweenness'. The measure is based on the number of shortest paths a firm is involved in between two randomly chosen actors. The higher than average betweenness value of spinoff companies suggests that they are more important in terms of connecting other firms in the cluster knowledge network. Closeness is calculated as the reciprocal of the sum of the length of the shortest paths between the firm and all other actors in the network. The higher average closeness value of spinoffs suggests that they can have faster, more direct access to other companies in the knowledge network. These descriptive statistics suggest that spinoffs are on average more embedded in the cluster knowledge network. Additionally, Fig. 3 in the Appendix shows that spinoff companies do not follow the same pattern to seek for technical advice. Even though the old Petöfi Press is the parent company of the majority of the spinoffs, it seems that they do not have identical relationships. However, by the application of ERGMs, I was able to test whether spinoff background matters for knowledge tie formation, while I also provide controls for further structural-, dyadic- and node-level characteristics at the same time.

Table 3 presents the results of two different ERGM specifications. To find the best-fitting ERGM setting, multiple alternative models have to be run until the model becomes stable, converges and provides the best 'goodness-of-fit' statistics. Similar to other studies applying ERGMs on knowledge networks (e.g. Broekel and Hartog 2013a, b; Capone and Lazzeretti 2016), I decided to present my main, theory-driven model and an improved ERGM to represent the stability of the results. The final, refined model is characterised by appropriate goodness-of-fit statistics, and related tables and figures are provided in the Appendix (Figs. 4 and 5). Note that the best-fitting, stable, converging model should have matching in-degree, minimum geodesic distance and edgewise shared partner distributions compared to the observed network. Moreover, the parameter traces for every variable should be horizontal.

To begin at the node level, the main variable on spinoff companies turned out to be positive and significant. It means that spinoff companies form significantly more ties than non-spinoffs while controlling for other factors. This is in line with my expectation and suggests that spinoffs are more capable to collaborate and form linkages to exchange knowledge in the cluster knowledge network. The wider consequences and possible reasons for this result are discussed in the conclusions section (Section 6). The similarity of ownership has a positive and significant effect, too. This indicates that knowledge ties are more easily formed within the group of domestic or foreign firms than across these groups. The reason behind this notion could be the barriers of 
Table 3 Results of the exponential random graph model

\begin{tabular}{|c|c|c|c|c|}
\hline & \multicolumn{2}{|l|}{ Main model } & \multicolumn{2}{|l|}{ Refined model } \\
\hline & Coefficient & (SE) & Coefficient & (SE) \\
\hline Spinoff & $0.3699 * *$ & $(0.124)$ & $0.4272 * * *$ & $(0.1286)$ \\
\hline Ownership group & $0.5120 * * *$ & $(0.1536)$ & $0.4939 * * *$ & $(0.1442)$ \\
\hline Extra-regional knowledge ties & $0.0128 *$ & $(0.0063)$ & $0.0149 *$ & $(0.0062)$ \\
\hline Age (experience) & 0.0204 & $(0.0434)$ & & \\
\hline Employment (log) & 0.0204 & $(0.0434)$ & 0.0133 & $(0.0474)$ \\
\hline Geographical proximity & $0.1059 * *$ & $(0.0355)$ & $0.1214 * * *$ & $(0.0361)$ \\
\hline Cognitive proximity & 0.0121 & $(0.0436)$ & 0.0171 & $(0.0422)$ \\
\hline GWESP (fixed 0.32) & $1.7159 * * *$ & $(0.4722)$ & $1.9596 * * *$ & $(0.4640)$ \\
\hline GWDSP (fixed 1.725) & $-0.1769 * * *$ & $(0.0487)$ & $-0.1858 * * *$ & $(0.0491)$ \\
\hline GWIDEGREE (fixed 0.1325) & -0.7690 & $(0.5415)$ & & \\
\hline MUTUAL ties & $1.6632 * * *$ & $(0.2737)$ & $1.5988 * * *$ & $(0.2681)$ \\
\hline EDGES & $-4.2661 * * *$ & $(0.7913)$ & $-4.6813 * * *$ & $(0.7526)$ \\
\hline AIC & 733.6 & & 731.9 & \\
\hline $\mathrm{BIC}$ & 787.3 & & 776.7 & \\
\hline
\end{tabular}

Author's own data

Significance codes: $* * * p<0.001, * * p<0.01, * p<0.05$

language or the technological gap between foreign and domestic companies. This finding underlines previous results related to the importance of ownership structure in knowledge spillover effects (Elekes and Lengyel 2016). External knowledge ties turned out to have a positive but barely significant effect on local tie formation. It means that extra-regional knowledge ties are important, but do not necessarily influence local knowledge sharing. The age and size of firms do not determine their abilities to form local knowledge ties. To provide a more accurate estimation, years of experience were excluded from my final model, which further refined the results as smaller AIC and BIC statistics indicate.

At the dyad level, geographical proximity is characterised by a positive and significant coefficient. This finding suggests that physical proximity helps the formation of knowledge ties in clusters and further emphasises the importance of microlevel geography on knowledge sharing (e.g. Broekel and Boschma 2012; Balland et al. 2016). Cognitive proximity, on the other hand, does not influence tie formation in this case. This suggests that firms with a similar technological profile are less likely to collaborate and exchange knowledge. Similar effects were found for cognitive proximity previously by Broekel and Hartog (2013a) who also applied ERGMs to the knowledge network of the Dutch aviation industry. However, the results are not in line with the growing literature that finds the positive influence of cognitive proximity for tie formation of cluster networks (e.g. Broekel and Boschma 2012; Balland et al. 2016; Lazzeretti and Capone 2016).

At the structural level, the formation of triads measured by GWESP statistics turned out to be positive and significant, confirming the fact that a relatively large number of triangles exist in the network. In other words, firms that are directly linked are also more likely to link through indirect connections. The negative and significant GWDSP statistics indicate that two firms without a direct link are less likely to be indirectly connected. The coefficient of GWIDEGREE is negative and not significant which suggests that there is no preferential attachment mechanism in this case. To improve the main model, I removed GWIDEGREE from my model setting, which resulted in a much more accurate estimation. Furthermore, the positive and significant effect of MUTUAL ties suggests that firms reciprocate advice and knowledge sharing. The negative and significant coefficient of EDGES indicates that the network is less dense 
than exponential random networks, which is a common feature of networks representing social interactions (Snijders et al. 2006). In summary, the models suggest that controlling for node-level, dyad-level and structural-level interdependencies, spinoff companies form significantly more ties than other firms.

\section{Conclusions}

The main aim of this study was to present the influence of spinoff companies on knowledge tie formation in clusters. Applying ERGMs to capture how node-level, dyad-level and structural-level factors influence collaboration in the cluster, I show that spinoffs form more local knowledge ties than other actors. As spinoffs collaborate and share knowledge more easily, they might as well gain more from locally accumulated knowledge. This suggests that the pre-entry experience, inherited routines and capabilities of spinoffs indeed influence their ability to cooperate and exchange innovation-related knowledge, and thus, are better able to exploit the positive externalities of co-location. This study has also contributed to the emerging empirical studies on knowledge network formation in clusters (e.g. Giuliani 2013; Broekel and Hartog 2013a; Balland et al. 2016; Capone and Lazzeretti 2018) and has provided further insights on the influence of company ownership, geographical closeness and common third partners on knowledge tie formation between firms.

The study also aimed to connect the literature on informal knowledge networks to the literature on spinoffs in clusters. Pioneer studies on cluster networks found that the firms' ability to absorb knowledge is important for collaboration and knowledge sharing (Giuliani and Bell 2005; Giuliani 2007). The present paper would extend this line of argument by showing that inherited capabilities and previous experiences could also increase the abilities of firms to participate in cluster knowledge networks. Even though the results suggest that there is a strong relationship between spinoff background and knowledge sharing, further research is needed to understand the particular capabilities that enable spinoffs to be more capable of collaboration and knowledge sharing in cluster networks.

Despite the fact that the current study was unable to include variables on the specific inherited capabilities of companies that might influence their ability to form ties, the face-to-face interviews with firm representatives provided several points to discuss. Through these conversations, I got to know more about the history of the local printing industry and the role of spinoff companies on informal network formation. An interesting conclusion resulting from the conversations is that since most of the actors know the other firms' representatives personally, there is a strong informal network behind the cluster. This shed light on the importance of historical aspects. I am becoming increasingly aware that a great number of companies started as a spinoff of the old Petófi Press where their founders learned the profession and most of them know each other personally from those formative learning years. Many of the interviewed representatives explained that they accumulated relevant experience, up-to-date professional knowledge and personal relationships as an employee, which enabled them to start their firm as a spinoff in an industry with which they were already familiar. They also explained that the confidence in their own technological capabilities helped them bravely interact and ask for technical help at the beginning of their career. This reinforced my impression that pre-entry experience and inherited capabilities are indeed essential for collaboration and also led me to the conclusion that spinoffs inherit personal relationships too, which might well influence their ability to collaborate and share knowledge in the future.

Since this exercise is based on a printing and paper product cluster in its later life-cycle stage, conclusions might be seen as being limited to clusters in traditional manufacturing industries. In addition, an important issue for future research is the extent of access to detailed, longitudinal data on knowledge transfer. The analysis here is based on relational data from only one point in time, however, and more detailed, longitudinal datasets on knowledge exchange in clusters could help answer several, still open, questions. First of all, the incorporation of firm entry, exit or the differentiation in generations of spinoffs could help 
change our understanding of network formation drastically. It could also make clear whether spinoff formation is a result of informal collaborations or rather of a more intense knowledgesharing environment emerging from spinoff foundations. Detailed information on parent companies would make it possible to test whether firms that gave birth to spinoffs are more capable of collaborating in the local knowledge network. Secondly, by using relational data on the individual level rather than firm level, I might understand more accurately the motivations behind tie formation. Moreover, the direct measurement of how inherited network ties matter for industry clusters is also a promising area for future research (Bagley 2018). Further insights on the extent to which firms and entrepreneurs build on inherited capabilities, routines and previous experiences would help us understand better why spinoffs form more ties than other companies in clusters.

In this study, I have only emphasised the role of spinoff companies in a cluster knowledge network. As recent studies have highlighted, structural-, dyadic- and actor-level characteristics might play a distinct role in the formation of different formal and informal cluster network types (Capone and Lazzeretti 2018; Balland et al. 2016; Ferriani et al. 2013). Therefore, it would be worth investigating the importance of spinoff companies in networks of business interaction, information flow, friendship and innovation. Further, I was unable to make any differentiation between the transmitted content of collaboration ties. However, the volume, diversity and depth of transferred information content could allow us to investigate how the value of advice influences tie formation (Aral and Van Alstyne 2011). Moreover, it would be interesting to see how the network position of spinoffs influences both their survival and the long-term prosperity they experience in cluster environments.

Acknowledgements The author acknowledges the comments and suggestions of Balázs Lengyel, Ron Boschma, Andrea Morrison, Gergő Tóth, Zoltán Elekes and András London on previous versions of the manuscript.

Funding information Open access funding provided by MTA Centre for Economic and Regional Studies (MTA KRTK). This research was supported by the EU-funded Hungarian grant EFOP3.6.2-16-2017-00007. The author received financial support from the ÚNKP-18-3 New National Excellence Program of the Ministry of Human Capacities, Hungary.

\section{Appendix 1. Concentration of manufacturing industries in the urban agglomeration of Kecskemét, Hungary}

Concentration of economic activities in the urban agglomeration of Kecskemét was measured by the location quotient (LQ). The basic equation for LQ is the following:

$\mathrm{LQ}=\frac{\frac{E_{i, j}}{E_{j}}}{\frac{E_{i, n}}{E_{n}}}$

where $E_{i, j}$ stands for the number of employees in industry $i$, in region $j ; E_{j}$ stands for the overall employment in region $j ; E_{i, n}$ represents the number of employees in the industry $i$ countrywide; and $E_{n}$ stands

Table 4 Location quotients (LQ) based on the number of employees in all the manufacturing industries in the urban agglomeration of Kecskemét, Hungary

\begin{tabular}{|c|c|c|}
\hline Code & Manufacturing (subsections) & LQ \\
\hline $\mathrm{CA}$ & $\begin{array}{l}\text { Manufacture of food products, beverages and } \\
\text { tobacco products }\end{array}$ & 1.884 \\
\hline $\mathrm{CB}$ & $\begin{array}{l}\text { Manufacture of textiles, apparel, leather and related } \\
\text { products }\end{array}$ & 0.610 \\
\hline $\mathrm{CC}$ & $\begin{array}{l}\text { Manufacture of wood and paper products, and } \\
\text { printing }\end{array}$ & 1.661 \\
\hline $\mathrm{CD}$ & $\begin{array}{l}\text { Manufacture of coke and refined petroleum } \\
\text { products }\end{array}$ & 0.000 \\
\hline $\mathrm{CE}$ & Manufacture of chemicals and chemical products & 0.085 \\
\hline $\mathrm{CF}$ & $\begin{array}{l}\text { Manufacture of pharmaceuticals, medicinal } \\
\text { chemical and botanical products }\end{array}$ & 0.000 \\
\hline $\mathrm{CG}$ & $\begin{array}{l}\text { Manufacture of rubber and plastics products and } \\
\text { other non-metallic mineral products }\end{array}$ & 0.848 \\
\hline $\mathrm{CH}$ & $\begin{array}{l}\text { Manufacture of basic metals and fabricated metal } \\
\text { products, except machinery and equipment }\end{array}$ & 0.990 \\
\hline $\mathrm{CI}$ & $\begin{array}{l}\text { Manufacture of computer, electronic and optical } \\
\text { products }\end{array}$ & 0.610 \\
\hline CJ & Manufacture of electrical equipment & 1.682 \\
\hline CK & Manufacture of machinery and equipment n.e.c. & 0.863 \\
\hline $\mathrm{CL}$ & Manufacture of transport equipment & 1.179 \\
\hline $\mathrm{CM}$ & $\begin{array}{l}\text { Other manufacturing, and repair and installation of } \\
\text { machinery and equipment }\end{array}$ & 0.558 \\
\hline
\end{tabular}

Author's own calculation based on the database of the Hungarian Central Statistical Office (Company Code Register 2010) 
Table 5 Location quotient (LQ) based on the number of employees in the printing and paper product industry in the urban agglomeration of Kecskemét, Hungary

\begin{tabular}{rlc}
\hline Sectors & LQ \\
\hline 16 & $\begin{array}{l}\text { Manufacture of wood and of products of wood and } \\
\text { cork, except furniture; manufacture of articles of } \\
\text { straw and plaiting materials }\end{array}$ & 2.348 \\
16.1 & Sawmilling and planing of wood \\
16.2 & Manufacture of products of wood, cork, straw and & 2.699 \\
17 & Manufacture of paper and paper products & 3.777 \\
17.1 & Manufacture of pulp, paper and paperboard & 0.000 \\
17.2 & Manufacture of articles of paper and paperboard & 4.602 \\
18 & Printing and reproduction of recorded media & 1.048 \\
18.1 & Printing and service activities related to printing & 1.059 \\
18.2 & Reproduction of recorded media & 0.393 \\
\hline
\end{tabular}

Author's own calculation based on Nace Rev. 2 and the database of the Hungarian Central Statistical Office (Company Code Register 2010)

for the number of employees in every sector in the country. In other words, the numerator is the share of a given industry in the region and the denominator is the share of this industry in the overall country. This index is also known as the index of revealed comparative advantage (RCA) or the Hoover-Balassa index following Balassa (1965).

Concentration can be measured on different bases, such as on employment, export or the number of companies. In this case, I choose to measure the concentration of employment in different sectors. I excluded firms with 1 or less than 1 employee, similar to Lengyel et al. (2018). Values higher than 1 of the index represent relative high concentration. This study focuses on printing and paper product creation in the urban agglomeration of Kecskemét. The sectors have relatively high concentration (see Tables 4 and 5) and tradition, and their value chain is typically related (see European Commission 2013).

Appendix 2. Descriptive statistics of the applied dyadic variables

Both of the presented ERGMs contain two dyad-level control variables: the geographical and cognitive proximity of firms. Geographical proximity is measured as the distance of the selected pair of firms subtracted from the maximum distance between any firm in the cluster. In this setting, the variables take a higher value as the physical distance between companies diminishes. The distribution of all the values of geographical proximity and the distribution of geographical proximity values in the case of observed knowledge ties are presented in Table 6.

The applied cognitive proximity measure is based on the number of digits the two firms have in common in their 4-digit NACE codes. This measure assumes that two firms have more similar technological profile and, therefore, are cognitively closer if they operate at the same sector category. The final sample consists of 26 companies and only $21 \%$ of all the possible firm pairs have cognitive proximity values of $4,33 \%$ have 3 and $46 \%$ have 0 as cognitive proximity measure. As the cognitive proximity values of 1 and 2 are missing, I also tested both the main model and the refined model with the cognitive proximity values of $0-1-$ 2 as robustness checks. Results showed no difference.
Fig. 3 Visual representation of how spinoffs seek for advice in the cluster (author's own data)

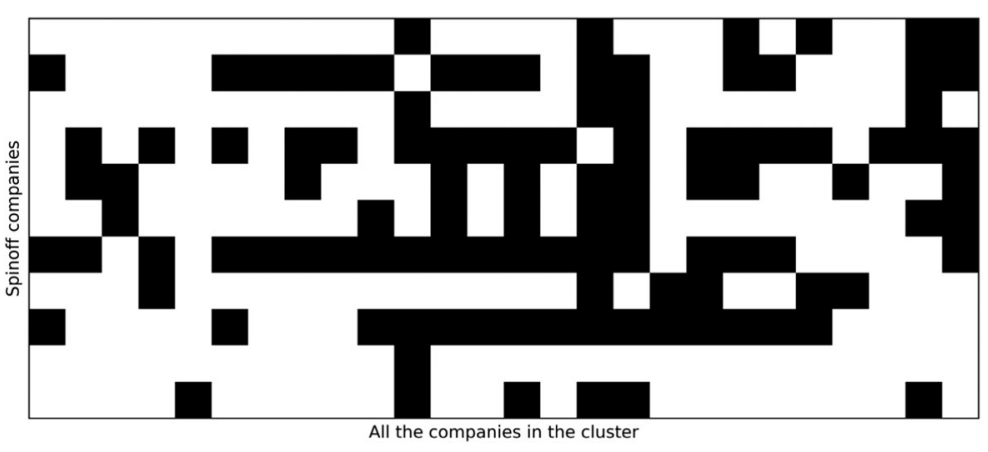




\section{Goodness-of-fit diagnostics}

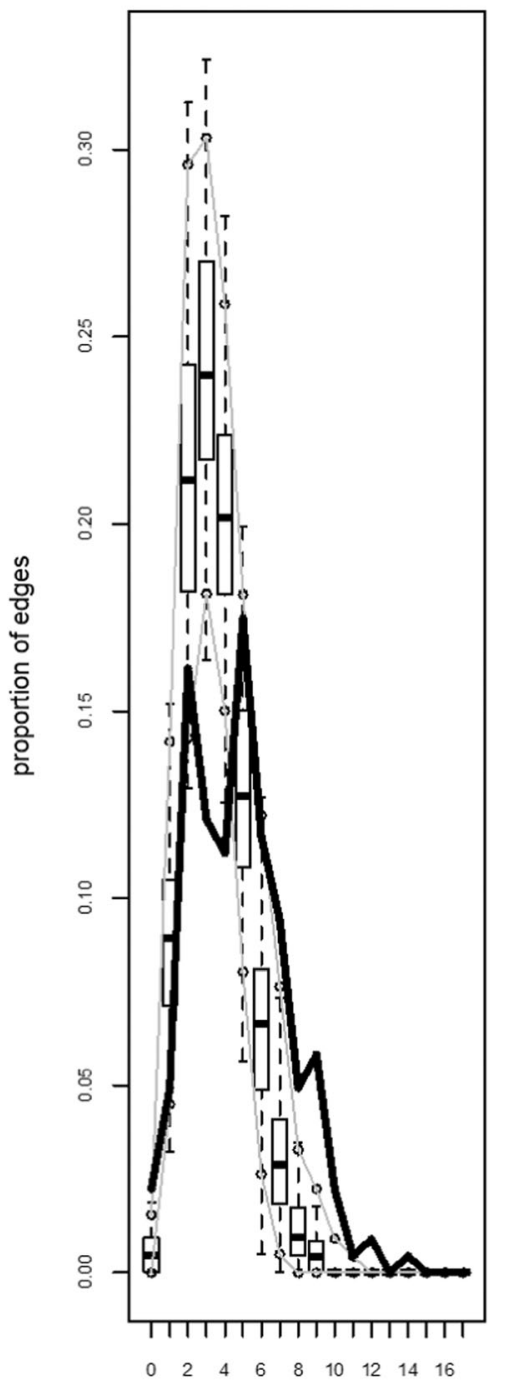

edge-wise shared partners
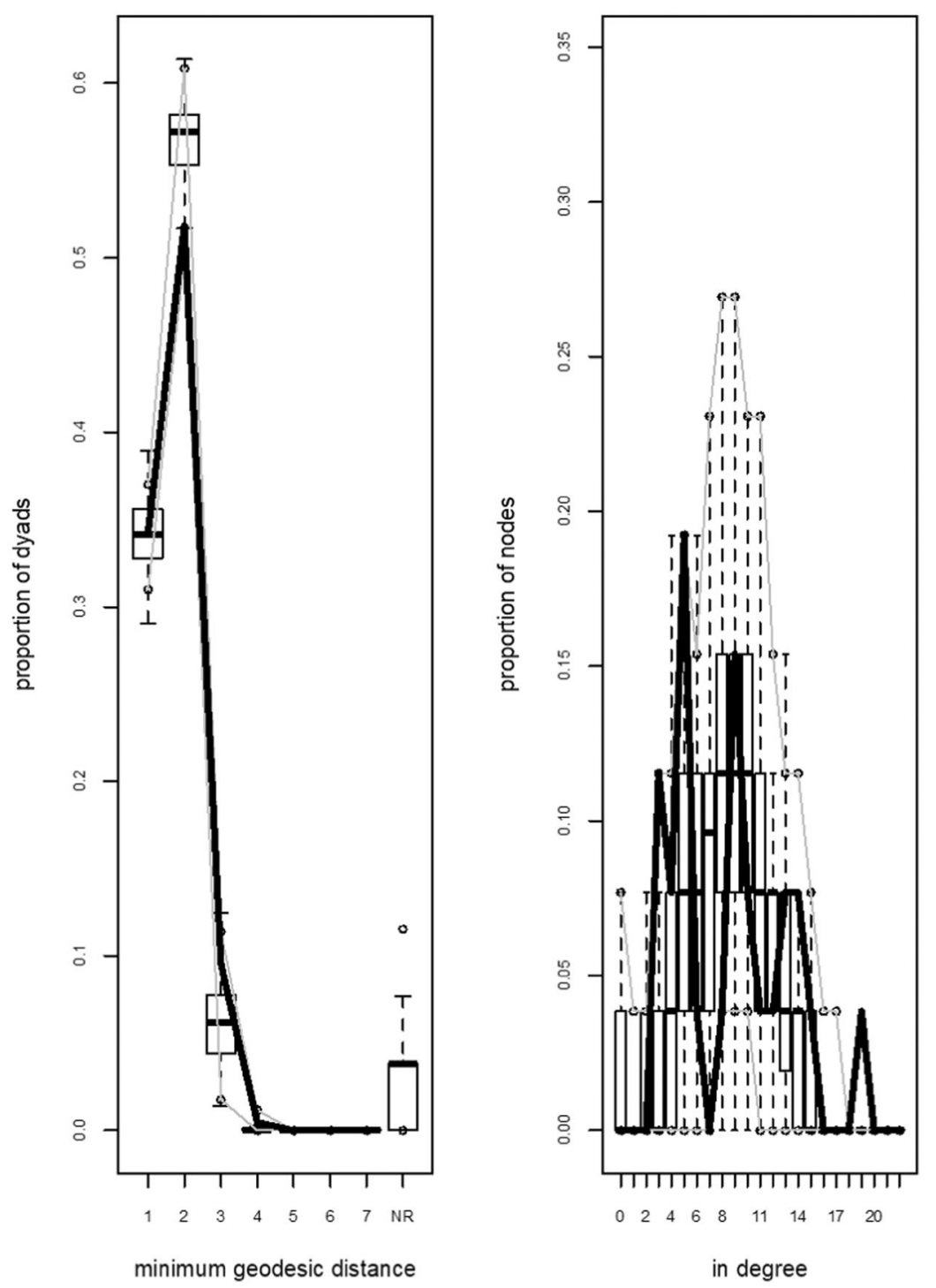

Fig. 4 Goodness-of-fit for the refined ERGMs

\section{Appendix 4. Patterns in advice seeking of spinoff companies}

Figure 3 is a slice of the adjacency matrix where rows represent how spinoff companies ask for technical knowledge and columns represent all the firms as potential knowledge sources in the cluster. The aim of the figure is to visualise that spinoff companies do not follow the same pattern to seek for advice. Even though the old Petöf $i$
Press is the parent company of the majority of the spinoffs, it seems that they do not have identical relationships.

Appendix 4. Goodness-of-fit statistics for the applied ERGMs 


\section{a}

Sample statistics
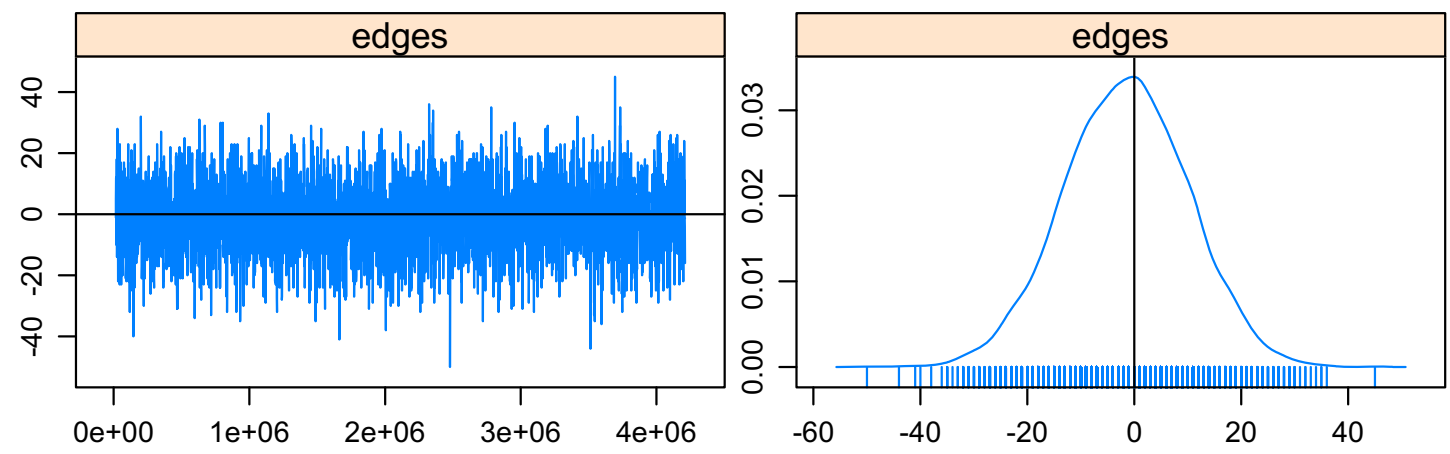

$\circ \longdiv { \text { mutual } }$
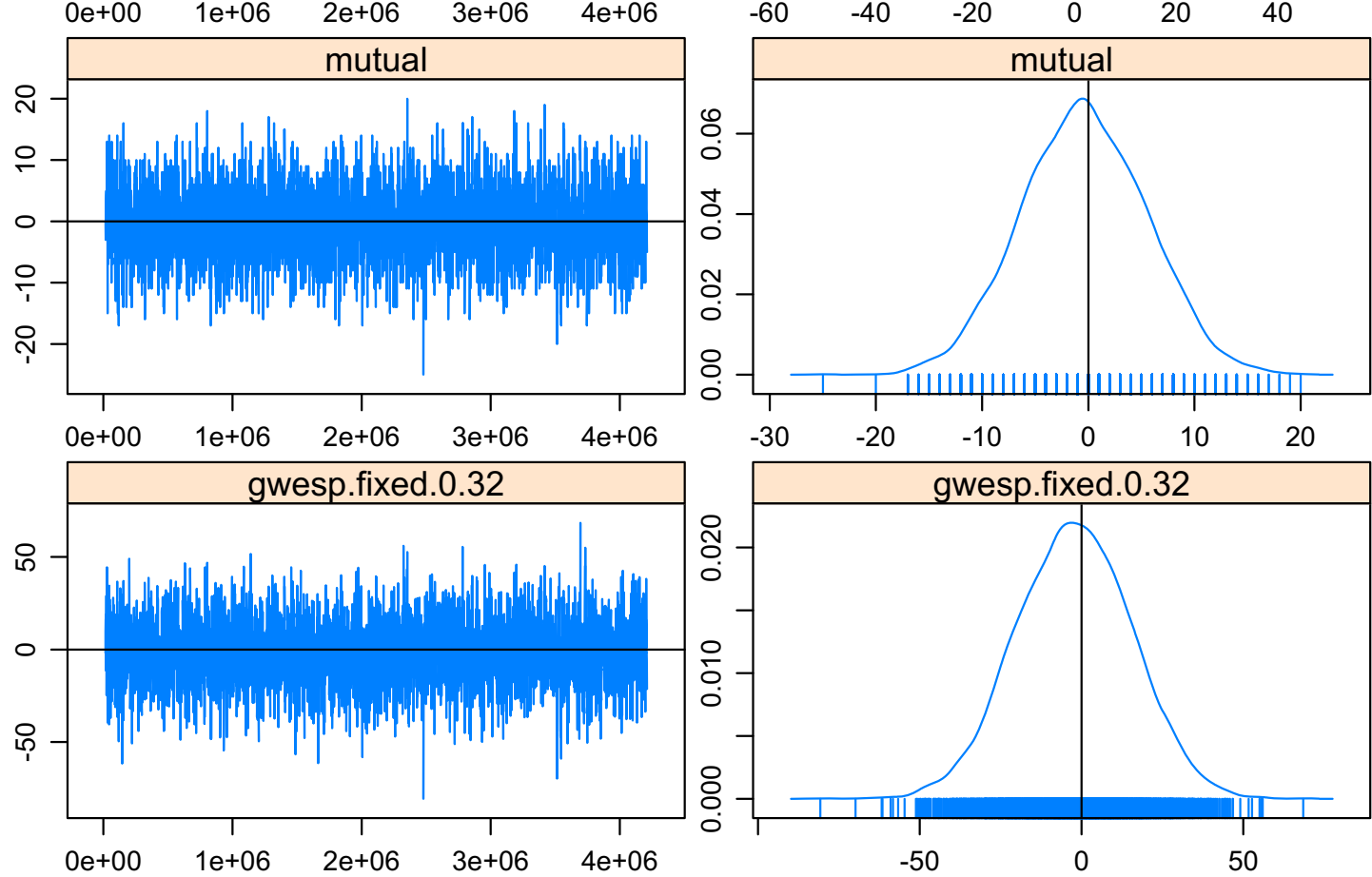

Fig. 5 a-d Goodness-of-fit for the refined ERGMs 
b

\section{Sample statistics}
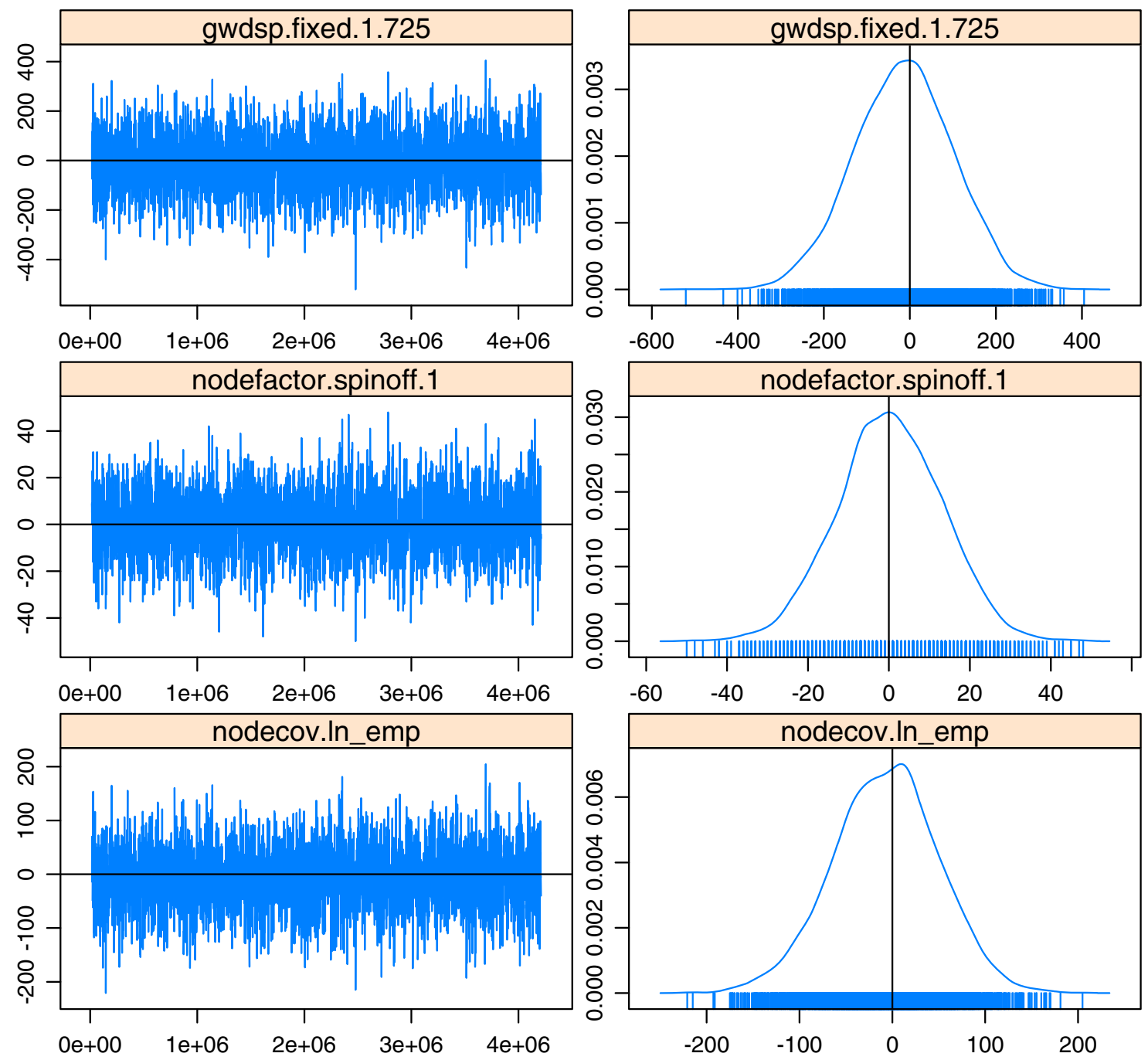

Fig. 5 continued. 
c

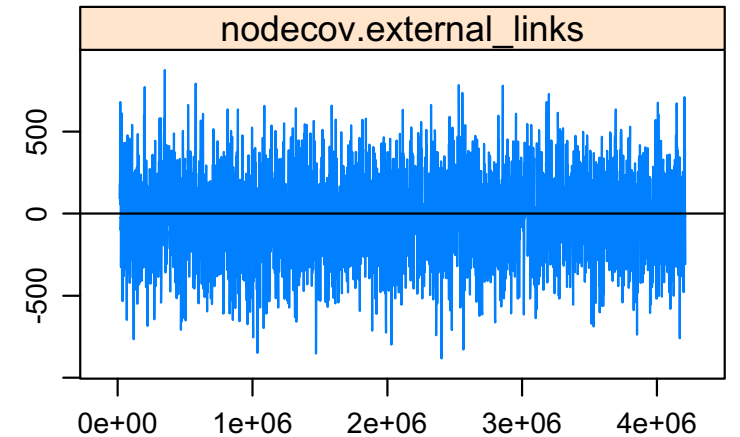

Sample statistics

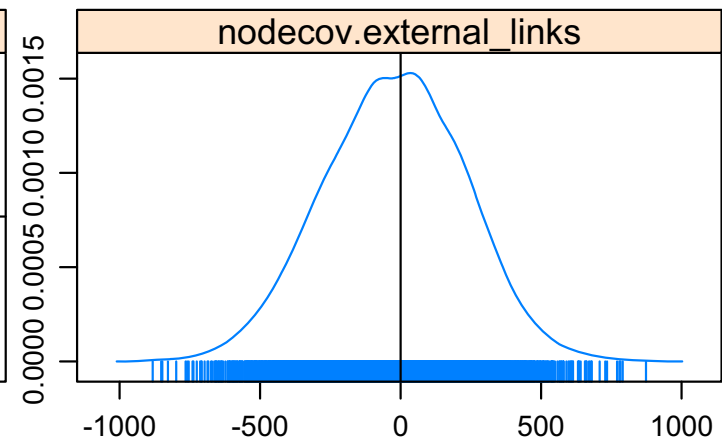

nodematch.f_owner
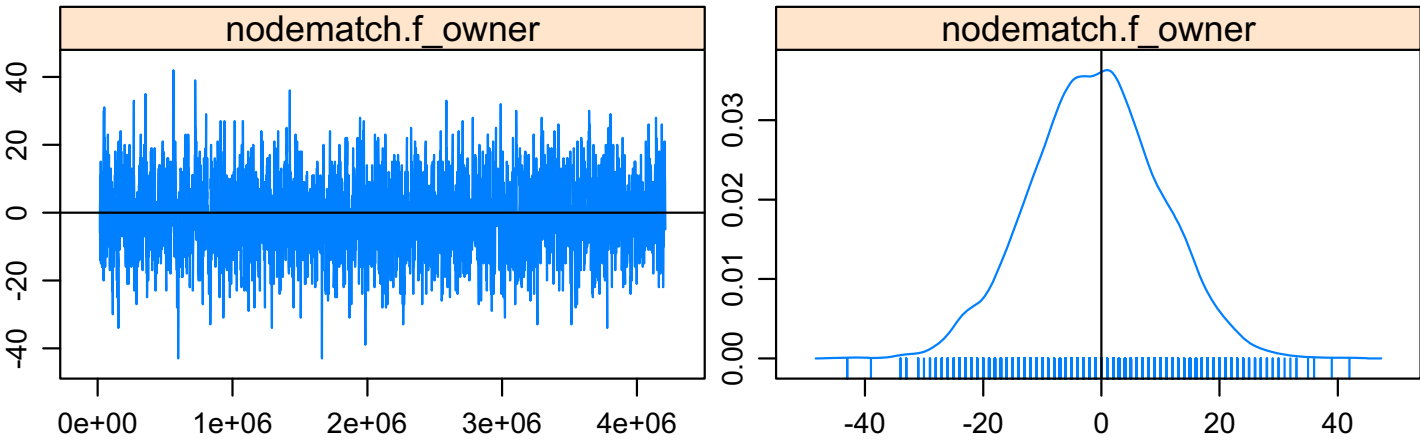

edgecov.geoprox

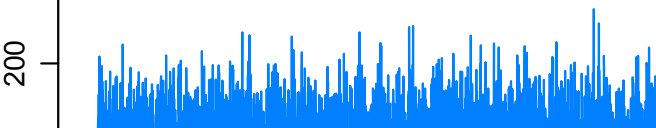

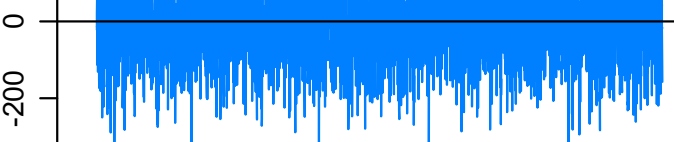

ণ
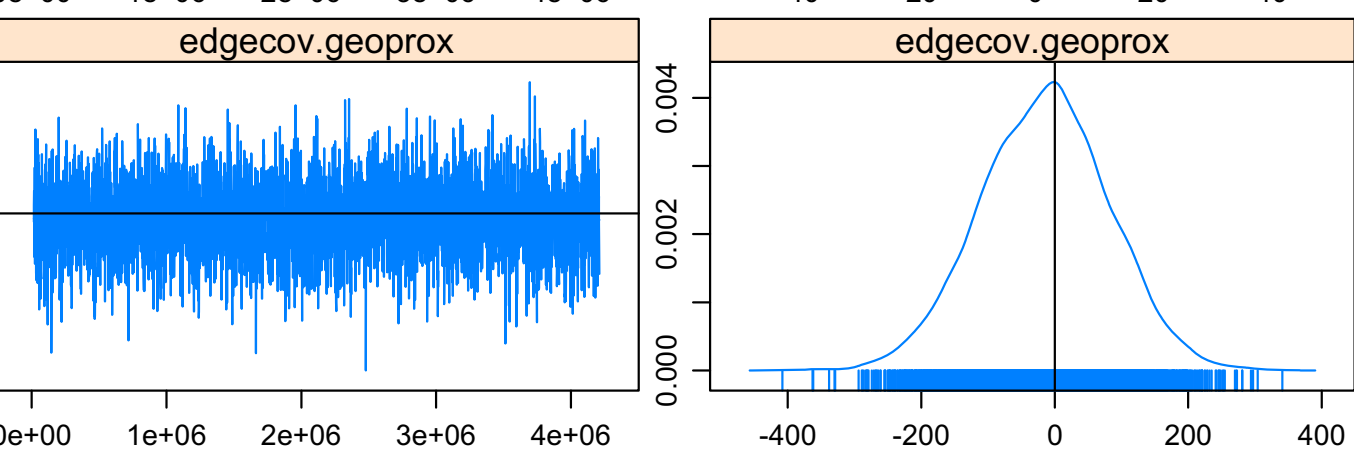

d Sample statistics
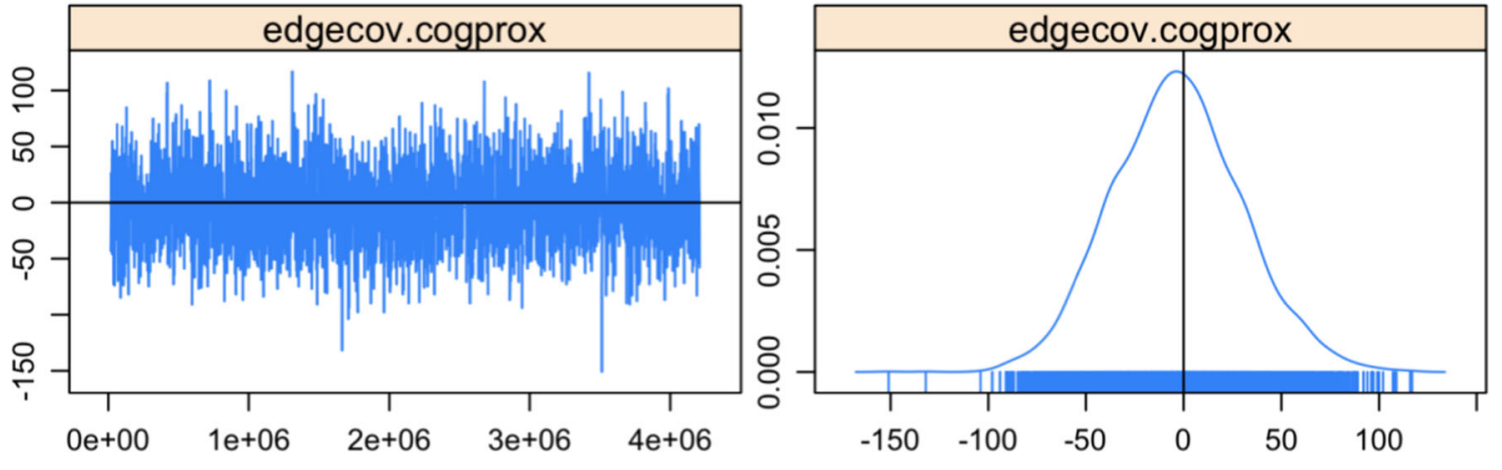

Fig. 5 continued. 
Table 6 Descriptive statistics of geographical proximity

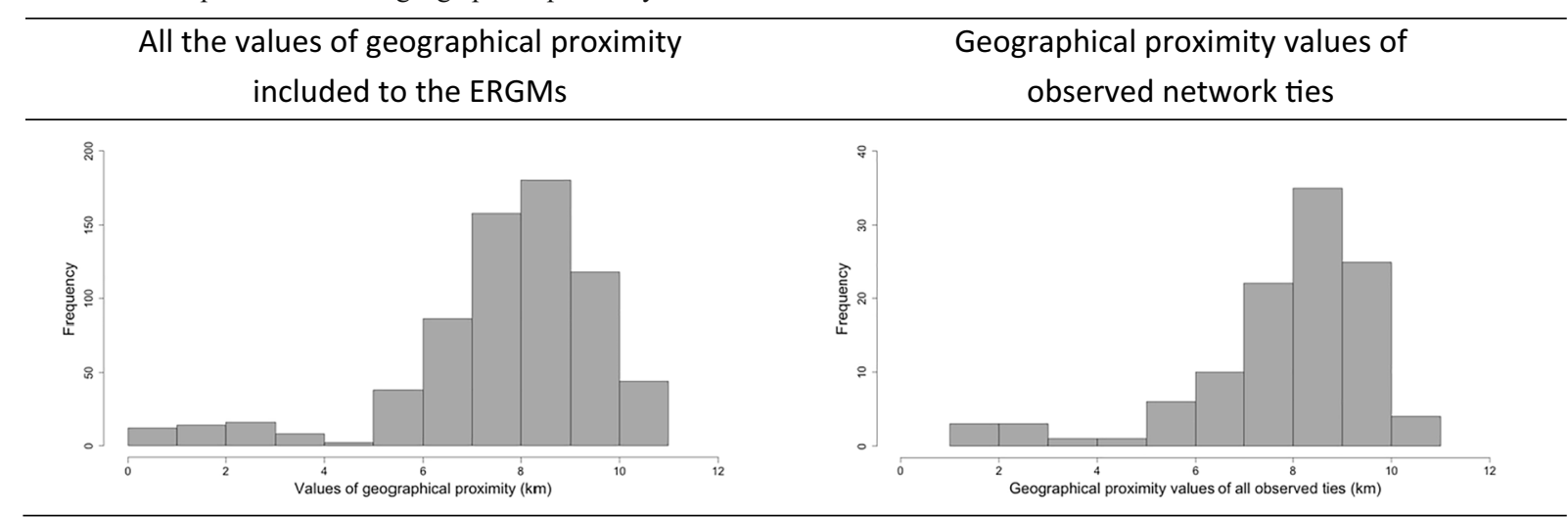

Author's own data

Table 7 Descriptive statistics of cognitive proximity

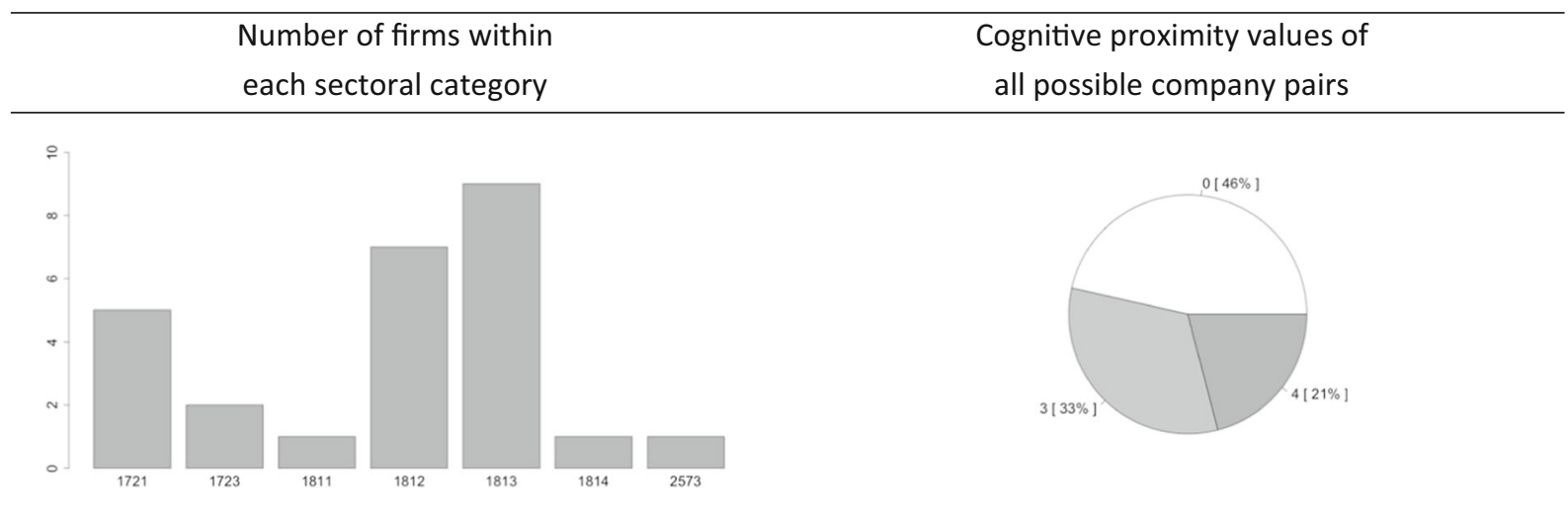

Author's own data

Open Access This article is distributed under the terms of the Creative Commons Attribution 4.0 International License (http:// creativecommons.org/licenses/by/4.0/), which permits unrestricted use, distribution, and reproduction in any medium, provided you give appropriate credit to the original author(s) and the source, provide a link to the Creative Commons license, and indicate if changes were made.

\section{References}

Agarwal, R., Echambadi, R., Franco, A. M., \& Sarkar, M. B. (2004). Knowledge transfer through inheritance: spin-out generation, development, and survival. Academy of Management Journal, 47(5), 501-522.

Aral, S., \& van Alstyne, M. (2011). The diversity-bandwidth trade-off. American Journal of Sociology, 117(1), 90-171.

Armstrong, J. S., \& Overton, T. S. (1977). Estimating nonresponse bias in mail surveys. Journal of Marketing Research, 14(3), 396-402.
Asheim, B. (1996). Industrial districts as learning regions: a condition for prosperity. European Planning Studies, 4(4), 379-400.

Audretsch, D. B., \& Feldman, M. P. (1996). R\&D spillovers and the geography of innovation and production. The American Economic Review, 86(3), 630-640.

Bagley, M. J. O. (2018). Small worlds, inheritance networks and industrial clusters. Industry and Innovation, (forthcoming). doi: https://doi.org/10.1080/13662716.2018.1539650.

Balassa, B. (1965). Trade liberalization and revealed comparative advantage. The Manchester School, 33, 99-123.

Balland, P.-A., Belso-Martínez, J. A., \& Morrison, A. (2016). The dynamics of technical and business networks in industrial clusters: embeddedness, status or proximity? Economic Geography, 92(1), 35-60.

Bathelt, H., Malmberg, A., \& Maskell, P. (2004). Clusters and knowledge: local buzz, global pipelines and the process of knowledge creation. Progress in Human Geography, 28(1), 31-56.

Boschma, R. (2015). Do spinoff dynamics or agglomeration externalities drive industry clustering? A reappraisal of Steven 
Klepper's work. Industrial and Corporate Change, 24(4), 859-873.

Boschma, R., \& Frenken, K. (2010). The spatial evolution of innovation networks. A proximity perspective. In R. Boschma \& R. Martin (Eds.), The handbook of evolutionary economic geography (pp. 120-135). Cheltenham: Edward Elgar.

Boschma, R., \& Ter Wal, A. L. J. (2007). Knowledge networks and innovation performance in an industrial district: the case of a footwear district in the south of Italy. Industry and Innovation, 14(2), 177-199.

Boschma, R., \& Wenting, R. (2007). The spatial evolution of the British automobile industry: does location matter? Industrial and Corporate Change, 16(2), 213-238.

Broekel, T., \& Boschma, R. (2012). Knowledge networks in the Dutch aviation industry: the proximity paradox. Journal of Economic Geography, 12(2), 409-433.

Broekel, T., \& Hartog, M. (2013a). Explaining the structure of inter-organizational networks using exponential random graph models. Industry and Innovation, 20(3), 277-295.

Broekel, T., \& Hartog, M. (2013b). Determinants of cross-regional $\mathrm{R} \& \mathrm{D}$ collaboration networks: an application of exponential random graph models. In T. Scherngell (Ed.), The geography of networks and R\&D collaborations (pp. 49-70). Cham: Springer.

Broekel, T., Balland, P.-A., Burger, M., \& van Oort, F. (2014). Modeling knowledge networks in economic geography: a discussion of four methods. The Annals of Regional Science, 53(2), 423-452.

Buenstorf, G., \& Guenther, C. (2011). No place like home? Relocation, capabilities, and firm survival in the German machine tool industry after World War II. Industrial and Corporate Change, 20(1), 1-28.

Buenstorf, G., \& Klepper, S. (2009). Heritage and agglomeration: the Akron tyre cluster revisited. The Economic Journal, 119(537), 705-733.

Buenstorf, G., \& Klepper, S. (2010). Why does entry cluster geographically? Evidence from the US tire industry. Journal of Urban Economics, 68(2), 103-114.

Capone, F., \& Lazzeretti, L. (2016). Interorganisational networks and proximity: an analysis of $R \& D$ networks for cultural goods. Sinergie, 34(101), 53-70.

Capone, F. and Lazzeretti, L. (2018). The different roles of proximity in multiple informal network relationships: evidence from the cluster of high technology applied to cultural goods in Tuscany. Industry and Innovation, published online, 2018 March 13.

Carias, C. and Klepper S. (2010). Entrepreneurship, the initial labor force, and the location of new firms. Paper presented at the International Schumpeter Society Conference, Aalborg, 2010/0621-24.

Cooke, P. (2002). Knowledge economies (Clusters, learning and cooperative advantage). London: Routledge.

Cusmano, L., \& Morrison, A. (2015). Spin-off and clustering: a return to the Marshallian district. Cambridge Journal of Economics, 39(1), 49-66.

Dahl, M. S., \& Sorenson, O. (2012). Home sweet home: entrepreneurs' location choices and the performance of their ventures. Management Science, 58(6), 1059-1071.
De Stefano, D., \& Zaccarin, S. (2013). Modelling multiple interactions in science and technology networks. Industry and Innovation, 20(3), 221-240.

Elekes, Z. and Lengyel, B. (2016). Related trade linkages, foreign firms and employment growth in less developed regions. Papers in Evolutionary Economic Geography, Nr. 16.20.

European Commission (2013). A blueprint for the EU forest-based industries. Brussels, Belgium. Online: https://eur-lex.europa. eu/legal-content/EN/TXT/PDF/?uri=CELEX:52013 SC0343 $\&$ from $=\mathrm{EN}$.

Eurostat. (2008). Nace Rev. 2. Statistical classification of economic activities in the European community. Luxembourg: European Communities.

Feldman, M., Francis, J., \& Bercovitz, J. (2005). Creating a cluster while building a firm: entrepreneurs and the formation of industrial clusters. Regional Studies, 39(1), 129-141.

Ferriani, S., Fonti, F., \& Corrado, R. (2013). The social and economic bases of network multiplexity: exploring the emergence of multiplex ties. Strategic Organization, 11(1), 7-34.

Fornahl, D., \& Brenner, T. (2003). Cooperation, networks and institutions in regional innovation systems. Cheltenham: Edward Elgar.

Frenken, K., Van Oort, F., \& Verburg, T. (2007). Related variety, unrelated variety and regional economic growth. Regional Studies, 41(4), 685-697.

Gertler, M. S. (2003). Tacit knowledge and the economic geography of context, or the undefinable tacitness of being (there). Journal of Economic Geography, 3(1), 75-99.

Giuliani, E. (2007). The selective nature of knowledge networks in clusters: evidence from the wine industry. Journal of Economic Geography, 7(2), 139-168.

Giuliani, E. (2010). Clusters, networks and economic development: an evolutionary economics perspective. In Boschma, R. and Martin, R. (eds.) The handbook of evolutionary economic geography. Cheltenham: Edward Elgar.

Giuliani, E. (2013). Network dynamics in regional clusters: evidence from Chile. Research Policy, 42(8), 1406-1419.

Giuliani, E., \& Bell, M. (2005). The micro-determinants of mesolearning and innovation: evidence from a Chilean wine cluster. Research Policy, 34(1), 47-68.

Glückler, J. (2007). Economic geography and the evolution of networks. Journal of Economic Geography, 7(5), 619-634.

Goodreau, S. M., Handcock, M. S., Hunter, D. R., Butts, C. T., \& Morris, M. (2008). A statnet tutorial. Journal of Statistical Software, 24(9), 1-26.

Gordon, I. R., \& McCann, P. (2000). Industrial clusters: complexes, agglomeration and/or social networks? Urban Studies, 37(3), 513-532.

Heebels, B., \& Boschma, R. (2011). Performing in Dutch book publishing 1880-2008. The importance of entrepreneurial experience and the Amsterdam cluster. Journal of Economic Geography, 11(6), 1007-1029.

Hunter, D. R., Goodreau, S. M., \& Handcock, M. S. (2008). Goodness of fit for social network models. Journal of the American Statistical Association, 103(481), 248-258.

Iammarino, S., \& McCann, P. (2006). The structure and evolution of industrial clusters: transactions, technology and knowledge spillovers. Research Policy, 35(7), 1018-1036.

Juhász, S., \& Lengyel, B. (2018). Creation and persistence of ties in cluster knowledge networks. Journal of Economic Geography, 18(6), 1203-1226. 
Klepper, S. (2007). Disagreements, spinoffs, and the evolution of Detroit as the capital of the U.S. automobile industry. Management Science, 53(4), 616-631.

Klepper, S. (2009). Spinoffs: a review and synthesis. European Management Review, 6(3), 159-171.

Klepper, S. (2010). The origin and growth of industry clusters: the making of Silicon Valley and Detroit. Journal of Urban Economics, 67(1), 15-32.

Knoben, J., \& Oerlemans, L. A. G. (2006). Proximity and interorganizational collaboration: a literature review. International Journal of Management Reviews, 8(2), 71-89.

Krugman, P. (1991). Geography and trade. Cambridge, MA: MIT Press.

Lambert, D. M., \& Harrington, T. C. (1990). Measuring nonresponse in customer service mail surveys. Journal of Business Logistics, 11(2), 5-25.

Lazzeretti, L., \& Capone, F. (2016). How proximity matters in innovation network dynamics along with the cluster evolution. A study of the high technology applied to cultural goods. Journal of Business Research, 69(12), 5855-5865.

Lengyel, I., Vas, Z., Szakálné Kanó, I., \& Lengyel, B. (2018). Spatial differences of reindustrialization in post-socialist economy: manufacturing in the Hungarian counties. European Planning Studies, 25(8), 1416-1434.

Lusher, D., Koskinen, J., \& Robins, G. (2013). Exponential random graph models for social networks: theory, methods and applications. New York: Cambridge University Press.

Marshall, A. (1920). Principles of economics. London, UK: MacMillan.

Maskell, P., \& Malmberg, A. (1999). Localised learning and industrial competitiveness. Cambridge Journal of Economics, 23(2), 167-185.

Molina-Morales, F. X., Belso-Martinez, J. A., Mas-Verdú, F., \& Martinez-Cháfer, L. (2015). Formation and dissolution of inter-firm linkages in lengthy and stable networks in clusters. Journal of Business Research, 68(7), 1557-1562.

Morrison, A. (2008). Gatekeepers of knowledge within industrial districts: who they are, how they interact. Regional Studies, 42(6), 817-835.

Morrison, A., \& Boschma, R. (2019). The spatial evolution of the Italian motorcycle industry (1893-1993): Klepper's heritage theory revisited. Industrial and Corporate Change. https://doi.org/10.1093/icc/dty019.

Morrison, A., \& Rabellotti, R. (2009). Knowledge and information networks in an Italian wine cluster. European Planning Studies, 17(7), 983-1006.

Morrison, A., Rabellotti, R., \& Zirulia, L. (2013). When do global pipelines enhance the diffusion of knowledge in clusters? Economic Geography, 89(1), 77-96.

Nelson, R., \& Winter, S. (1982). An evolutionary theory of economic change. Belknap: Cambridge, MA.

Owen-Smith, J., \& Powell, W. W. (2004). Knowledge networks as channels and conduits: the effects of spillovers in the Boston biotechnology community. Organization Science, 15(1), 521.

Parra-Requena, G., Molina-Morales, F. X., \& Garcia-Villaverde, P. M. (2010). The mediating effect of cognitive social capital on knowledge acquisition in clustered firms. Growth and Change, 41(1), 59-84.
Porter, M. E. (1990). The competitive advantage of nations. London: Macmillan.

Qian, H. (2018). Knowledge-based regional economic development: a synthetic review of knowledge spillovers, entrepreneurship, and entrepreneurial ecosystems. Economic Development Quarterly, published online, 2018 March 07.

Rigby, D. L., \& Brown, W. M. (2015). Who benefits from agglomeration. Regional Studies, 49(1), 28-43.

Robins, R., Snijders, T., Wang, P., Handcock, M., \& Pattison, P. (2007a). Recent developments in the exponential random graph $\left(\mathrm{p}^{*}\right)$ models for social networks. Social Networks, 29(2), 192-215.

Robins, G., Pattison, P., Kalish, Y., \& Lusher, D. (2007b). An introduction to exponential random graph $\left(\mathrm{p}^{*}\right)$ models for social networks. Social Networks, 29(2), 173-191.

Rosenthal, S. S., \& Strange, W. C. (2004). Evidence on the nature and source of agglomeration economies. In V. Henderson \& J.-F. Thisse (Eds.), Handbook of regional and urban economics (pp. 2119-2171). Amsterdam: North-Holland.

Saxenian, A. (1994). Regional advantage culture and competition in Silicon Valley and Route 128. Cambridge, MA: Harvard University Press.

Snijders, T. (2002). Markov chain Monte Carlo estimation of exponential random graph models. Journal of Social Structure, 3(2), 1-40.

Snijders, T., Pattison, P. E., Robins, G. L., \& Handcock, M. S. (2006). New specifications for exponential random graph models. Sociological Methodology, 36(1), 99-153.

Sorenson, O., \& Audia, P. G. (2000). The social structure of entrepreneurial activity: geographic concentration of footwear production in the United States, 1940-1989. American Journal of Sociology, 106(2), 424-462.

Tallman, S., Jenkins, M., Henry, N., \& Pinch, S. (2004). Knowledge, clusters and competitive advantage. Academy of Management Review, 29(2), 258-271.

Ter Wal, A. L. J. (2013). Cluster emergence and network evolution: a longitudinal analysis of the inventor network in Sophia-Antipolis. Regional Studies, 47(5), 651-668.

Ter Wal, A. L. J., \& Boschma, R. (2009). Applying social network analysis in economic geography: framing some key analytic issues. The Annals of Regional Science, 43(3), 739-756.

Van Duin, M. A. J., Gille, K. J., \& Handcock, M. S. (2009). A framework for the comparison of maximum pseudolikelihood and maximum likelihood estimation of exponential family random graph models. Social Networks, 31(1), 52-62.

Wasserman, S., \& Faust, K. (1994). Social network analysis: methods and applications. Cambridge: Cambridge University Press.

Wenting, R. (2008). Spinoff dynamics and the spatial formation of the fashion design industry, 1858-2005. Journal of Economic Geography, 8(5), 593-614.

Publisher's note Springer Nature remains neutral with regard to jurisdictional claims in published maps and institutional affiliations. 